\title{
The association between mastitis and reproductive performance in seasonally-calved dairy cows managed on a pasture-based system
}

\author{
Asociación entre la mastitis y el desempeño reproductivo en rodeos lecheros Holstein de base \\ pastoril y servicios estacionados
}

\author{
CI Gómez-Cifuentes ${ }^{\mathrm{a}}$, AI Molineri ${ }^{\mathrm{b}}$, ML Signorini ${ }^{\mathrm{a}, \mathrm{b}, \mathrm{c}^{*}}$, D Scandolo ${ }^{\mathrm{b}}$, LF Calvinho ${ }^{\mathrm{a}, \mathrm{b}}$ \\ ${ }^{a}$ Facultad de Ciencias Veterinarias, Universidad Nacional del Litoral, Santa Fe, Argentina.

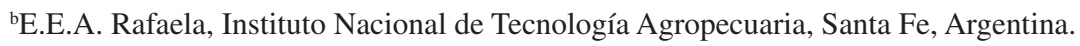 \\ ${ }^{\mathrm{c} C}$ Consejo Nacional de Investigaciones Científicas y Técnicas, Santa Fe, Argentina.
}

\begin{abstract}
RESUMEN
El objetivo de este trabajo fue determinar asociación entre mastitis clínicas, subclínicas y condición corporal con la performance reproductiva de vacas en un sistema de partos estacional bajo condiciones de pastoreo. Se analizó información de 182 vacas paridas durante 2008. Se realizó Chi cuadrado y regresión logística con preñez al final de la temporada de servicios y número de servicios como variables dependientes. Las mastitis clínicas, subclínicas y la condición corporal, así como otras posibles variables asociadas fueron analizadas como variables independientes. Número de lactancia, tipo de parto, intervalo entre parto a inicio de temporada de servicio y condición corporal estuvieron asociadas con preñez. Las vacas con una o dos lactancias $(\mathrm{P}=0,031)$, aquellas sin problemas en el parto $(\mathrm{P}=0,003)$ y las que tuvieron mayor cantidad de días entre el parto y el inicio de la temporada de servicios $(\mathrm{P}=0.001)$ y las que tuvieron una condición corporal $>2.5(\mathrm{P}=0.007)$ tuvieron más probabilidad de quedar preñadas. Las mastitis subclínicas afectaron la performance reproductiva aumentando el número de servicios $(\mathrm{P}=0.03)$. Además la temporada de servicios influyó sobre el número de servicios recibidos por vaca, ya que aquellas paridas en verano necesitaron más servicios para quedar preñadas $(\mathrm{P}=0.046)$. Las mastitis clínicas no estuvieron asociadas con preñez $(\mathrm{P}=0.863)$. La información obtenida puede ser utilizada para mejorar la performance reproductiva de rodeos bajo condiciones pastoriles y sistemas de servicios estacionados.
\end{abstract}

Palabras clave: mastitis clínica, mastitis subclínica, parámetros reproductivos, servicios estacionados.

\section{SUMMARY}

The objective of this study was to assess association between clinical, subclinical mastitis, body condition score and the reproductive performance of cows under seasonally calving conditions in a pasture-based management system. Data from 182 cows calved during 2008 were analyzed. Chi-square and logistic regression were performed considering pregnancy at the end of breeding season and number of services as dependent variables, whereas clinical and subclinical mastitis and other variables related to the animal that could have an effect on the dependent variables (e.g. parity, BCS, concurrent diseases) were considered as independent variables. Lactation number, calving difficulty, interval from calving to the beginning of breeding season and body condition score had a significant effect on pregnancy at the end of breeding season. Cows with one or two lactations $(\mathrm{P}=0.031)$, those with no difficulty at calving $(\mathrm{P}=0.003)$, those with more days from calving to the beginning of breeding season $(\mathrm{P}=0.001)$, and those with body condition score $>2.5(\mathrm{P}=0.007)$ were most likely to become pregnant. Subclinical mastitis affected reproductive performance increasing the number of services $(\mathrm{P}=0.03)$. Also, breeding season influenced number of services, since summer-calving cows needed more services to become pregnant $(\mathrm{P}=0.046)$. Clinical mastitis was not associated with pregnancy as a final measure of reproductive performance $(\mathrm{P}=0.863)$. Although subclinical mastitis influenced reproductive performance, several parameters related to reproductive and nutritional management, significantly affected the outcome variables under experimental conditions of this study. This information can be valuable to improve reproductive performance in similar management systems.

Key words: clinical mastitis, subclinical mastitis, reproductive performance, seasonal calving herd.

\section{INTRODUCTION}

The interval from calving to first service, heat detection rate, body condition along with negative energy balance, body weight in first breeding heifers and the per-

Accepted: 17.10 .2013 .

* $\quad$ Kreder 2805, Esperanza, C.P. S3080HOF, Santa Fe, Argentina; marcelo.signorini@gmail.com centage of milk protein, have been identified as the main factors affecting reproductive performance in seasonallycalved dairy cows (Morton 2000, Buckley et al 2003, Verkerk 2003, Mc Dougall 2006, Roche et al 2007). In addition, mastitis is another factor that has been related to low reproductive performance (Barker et al 1998, Schrick et al 2001). Mastitis is one of the most complex diseases of dairy cattle causing important economical loss to the dairy industry. The widespread occurrence of the disease 
in dairy herds leads to considerable loses to producers, including veterinary and treatment costs, reduced milk production, milk discarded due to antibiotic contamination, early culling, extra labour, decreased milk quality, and increased future disease risk (Petrovski et al 2006).

Clinical and subclinical mastitis are associated with an increase in the number of open animals, the interval from calving to first service and the number of services per conception (Barker et al 1998; Hockett et al 2000, 2005, Schrick et al 2001, Klaas et al 2004, Santos et al 2004). Different mechanisms by which mastitis may influence reproductive performance have been suggested. Briefly, cytokines released during the inflammatory process may lead to a failure in GnRH and gonadotrophin release in the preovulatory period (Hockett et al 2005, 2000, Schrick et al 2001). Mastitis may also induce the release of $\mathrm{PGF}_{2 \alpha}$ that leads to luteolysis during the postovulatory period and early pregnancy (Risco et al 1999, Hockett et al 2005).

The influence of mastitis on reproductive performance has been well studied in housed herds (Barker et al 1998; Hockett et al 2000, 2005, Schrick et al 2001); however, there are few reports from pasture-based systems (Washburn et al 2002). An insight into the association between mastitis (clinical or subclinical) and reproductive performance in seasonal calving herds based on pastures would help to measure the impact of the disease in this system type and might contribute to decision making regarding herd mastitis control as well as both reproductive and economic success of the dairy herd. The objective of this study was to evaluate the association between clinical and subclinical mastitis with reproductive performance in a seasonal calving dairy herd under a pasture-based management system.

\section{MATERIAL AND METHODS}

A herd of 260 lactating cows from Rafaela Research Station ( $31^{\circ} 11^{\prime}$ S latitude and $61^{\circ} 33^{\prime}$ W longitude) was used for the study. In average, 224 cows between their first and seventh lactations were in production. The average daily production per cow during the lactation period under study was $23.3 \mathrm{~L} \pm 6.2 \mathrm{~L}$. Heifers $(\mathrm{n}=45)$ were bred for the first time at 18 months General calving interval was 13.6 month and conception rate was $48 \%$ for all categories of parity.

The study period was between the last calving date and the last artificial insemination (AI) registered for both breeding seasons. The final database included complete records of a total of 182 animals. Cows that were culled during the experimental period and those with incomplete records were not included in the study. Cows were milked twice daily in a 16-stall herringbone milking parlor equipped with automatic take-offs and an automatic herd management system. Milking equipment was maintained according to the recommendations of the manufacturer. Cows were managed under grazing conditions and received a concentrate during milking time. The amount of each diet component ( $\mathrm{kg}$ of dry matter per cow) for lactating cows was adjusted according to season (autumn or spring) and production level (table 1). Concentrate composition was: corn $70 \%$, soy expeller $20 \%$, wheat bran; $8 \%$ calcium carbonate $1.2 \%$, salt $0.7 \%$, vitamin-mineral supplement $0.08 \%$, monensin $20 \%$.

All cows were dried off between 50 to 60 days before the expected calving day. Cows with clinical mastitis were diagnosed by milking personnel. Cows were observed for oestrous for thirty minutes twice daily by trained farm personnel aided by tail painting. Following calving, cows were generally subjected to a voluntary waiting period of $60 \mathrm{~d}$ prior to first AI. Postpartum reproductive examinations were performed on all cows among the puerperal period and after the voluntary waiting period. Pregnancy examinations were performed on all cows 50 to $65 \mathrm{~d}$ after AI.

The herd was divided into two groups $(\mathrm{n}=182)$ : one group ( $\mathrm{n}=102)$ was bred from May to July (autumn breeding season) and calved in summer, between February and April. The other group $(\mathrm{n}=80)$ was bred from October to December (spring breeding season) and calved in winter, between July and September.

Average temperature from May to July was $14.6{ }^{\circ} \mathrm{C}$ with $71.3 \%$ of humidity. In summer calving the average temperature was $22.2{ }^{\circ} \mathrm{C}$ with $73.3 \%$ humidity. From October to December the average temperature was 24.3 ${ }^{\circ} \mathrm{C}$ with $60 \%$ of relative humidity and in winter calving, $16^{\circ} \mathrm{C}$ with $66.6 \%$ relative humidity.

Measures of reproductive performance and udder health condition were entered in a dairy herd management system (D.H.M.S. ${ }^{\circledR}$, San Carlos, Argentina) database during 2008. Data included: the calving history through current year, reproductive performance (see below), health status, body condition score (BCS), clinical mastitis occurrence and milk somatic cell count. Somatic Cell Count (SCC) records were extracted from the monthly official dairy herd improvement system of Argentina.

\section{INDEPENDENT (EXPLANATORY) VARIABLES}

Calving. Parameters considered included: date of calving, calving season (summer or winter), lactation number, need of calving assistance (assisted or normal parturition) and occurrence of retained placenta (i.e. fetal membranes retained longer than $12 \mathrm{~h}$ after parturition). In addition, the interval between calving and the beginning of breeding season (CBSI) was considered.

Reproductive performance. Data included were: first service date, last AI date, and presence of reproductive diseases from calving to the latest day of AI recorded (metritis, endometritis, anoestrous, ovarian cysts). We defined anoestrous as the non occurrence of estrous, being the 
Table 1. Diet composition of low and high milk production cows in autumn and spring seasons.

Composición de la dieta de vacas de alta y baja producción en otoño y primavera.

\begin{tabular}{|c|c|c|c|}
\hline Ingredient & $\begin{array}{l}\text { Quantity in the diet (kg/DM) } \\
\text { (CD) }\end{array}$ & $\begin{array}{l}\text { Metabolic Energy } \\
(\text { Mcal/k DM) }\end{array}$ & $\begin{array}{c}\text { Protein digested } \\
(\% \mathrm{DM})\end{array}$ \\
\hline \multicolumn{4}{|c|}{ Autumn: Low production cows } \\
\hline Green alfalfa & 4.0 & 2.5 & 24.4 \\
\hline Corn silage & 7.0 & 2.8 & 8.9 \\
\hline Concentrate & 4.5 & 3.1 & 16.2 \\
\hline Cotton seed & 2.0 & 2.3 & 21.6 \\
\hline \multicolumn{4}{|c|}{ Autumn: High production cows } \\
\hline Green alfalfa & $6.5-7.0$ & 2.5 & 24.4 \\
\hline Corn silage & 7.3 & 2.8 & 8.9 \\
\hline Alfalfa hay & 0.8 & 2.2 & 19.2 \\
\hline Concentrate & 6.5 & 3.1 & 16.2 \\
\hline By-products & 2.9 & 2.5 & 32.9 \\
\hline \multicolumn{4}{|c|}{ Spring: Low production cows } \\
\hline Green alfalfa & 14.0 & 2.5 & 23.6 \\
\hline Concentrate & 4.0 & 3.1 & 16.2 \\
\hline \multicolumn{4}{|c|}{ Spring: High production cows } \\
\hline Green alfalfa & 10.0 & 2.5 & 23.6 \\
\hline Corn silage & 3.0 & 2.8 & 8.9 \\
\hline Alfalfa hay & 1.0 & 2.2 & 19.2 \\
\hline Concentrate & 6.0 & 3.1 & 16.2 \\
\hline By-products & 2.0 & 2.5 & 32.9 \\
\hline
\end{tabular}

female not sexually receptive at any time. The reproductive treatments were classified as: progesterone-releasing intravaginal device (PRID), prostaglandins (PG) or a combination of both. Diagnoses of reproductive diseases were performed by transrectal palpation.

Days to first AI (DFAI) were defined as days from the beginning of breeding season to first AI. Also, the number of days between the beginning of breeding season and the AI date after which cows were confirmed pregnant (Days to Effective AI, DEAI) was also considered. Health status. In order to avoid confounding factors, the presence of some metabolic diseases (acidosis, ketosis or milk fever) and foot problems were recorded, since these diseases can influence reproductive performance. Clinical examination, diagnosis and treatment were carried out by a staff veterinarian.

Body Condition Score (BCS). BCS was recorded at least once at the beginning of breeding season. A five-point scale was used with a score of five being obese and a score of one being emaciated (Edmonson et al 1989). Cows were scored in 0.25 -point increments and all scoring was by one individual.
Mastitis. Somatic cell count arithmetic averages were calculated for each animal from calving to the last service from the monthly information recorded. A subclinical mastitis case was defined as presence of SCC $>200,000$ cells/ml in two consecutive monthly milk controls (Schukken et al 2003).

Clinical mastitis was identified by milking personnel when abnormal milk was found during foremilk stripping. Foremilk samples from all quarters of cows with clinical mastitis were collected aseptically upon diagnosis and were subjected to bacteriological analysis following standard methods (Oliver et al 2004). Cows with signs of clinical mastitis were treated by intramammary injection with an approved antibiotic formula containing spiramycin, neomycin and flumethasone (Ememast $\left.{ }^{\circledR}\right)$ after each milking for three days. Clinical mastitis was considered recurrent when abnormal milk appeared in the same quarter, or in another quarter of the same cow, within the next 14 days.

\section{DEPENDENT (OUTCOME) VARIABLES}

The status at the end of breeding season (pregnant or non-pregnant) and the number of AI received along the 
breeding season, were considered as dependent variables. In the case of the number of AIs received in the breeding season, the animals were divided into two groups: a) animals with two or less AIs, and b) animals that needed more than two AIs.

\section{STATISTICAL ANALYSIS}

A logistic regression analysis in two stages was conducted. In the first stage, associations between the dependent variables and each of the independent variables were screened in univariate Chi-squared analysis. Variables with a $\mathrm{P}<0.20$ were then considered for further analysis provided that there was no co-linearity $(r<0.60)$ between variables. Co-linearity between variables was assessed pair-wise by calculation of Spearman rank correlations. In the second stage, variables associated with $\mathrm{P}<0.20$ in the univariate analysis were considered in a logistic regression analysis. The estimation method was maximum likelihood with a convergence criterion of 0.01 for a maximum of 10 interactions. In the final model a variable with a $\mathrm{P}<0.05$ was considered statistically significant and retained in the model. All analyses were performed using INFOSTAT $^{\circledR}$ (Universidad Nacional de Córdoba, Argentina).

\section{RESULTS}

\section{DESCRIPTIVE ANALYSIS}

Calving. During summer and winter 102 and 80 calves were born, respectively. Seventy per cent of the cows were between their first and third lactations. Parity was associated with assistance at calving time; with older cows being less likely to require assistance at parturition.

\section{Summer}

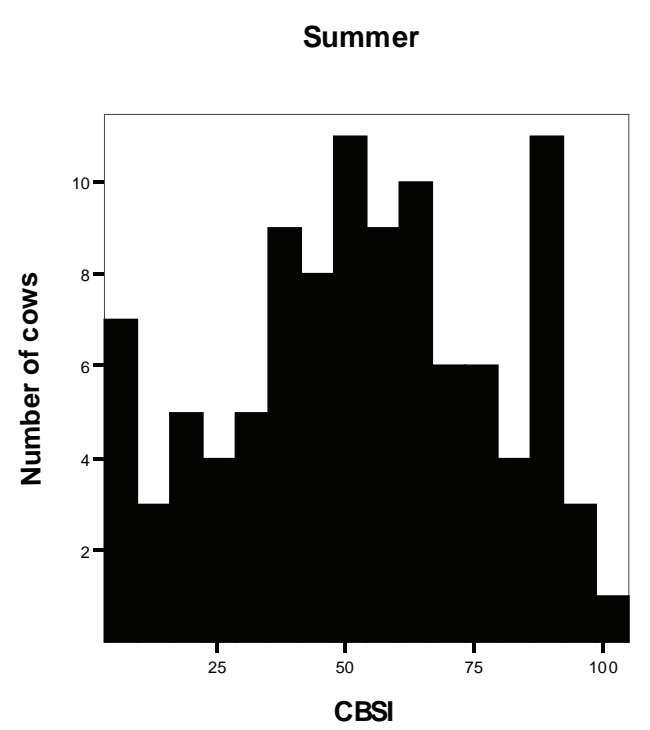

The CBSI distribution showed significant differences between breeding seasons $(\mathrm{P}<0.001)$. In summer calving $18.6 \%$ of the animals calved between 1 and 30 days before the beginning of the breeding season, $43.1 \%$ between 31 and 60 days and 38.2\% more than 60 days before. In winter season the averages were $6.3 \%, 26.3 \%$ and $67.5 \%$, respectively (figure 1). The CBSI distribution also showed significant differences according to lactation number $(\mathrm{P}=0.047)$. Cows from first and second lactation calved, in average, 63 days before the beginning of the breeding season and cows from parity 3 or more calved 55 days before.

Health status. During the studied period five cases of acidosis were diagnosed, 10 cases of foot lesions, 10 cases of retained placenta and eight of anoestrous. A significant association between anestrous and calving season was found $(\mathrm{P}=0.022)$. Cows calving in winter were 2.08 times more likely to present anestrous than those calving in summer. The other diseases diagnosed showed no significant association with the calving season.

Body Condition Score (BCS). BCS of 171 animals were recorded at least once during the breeding season. The lowest BCS was 1.75, the highest 4 (median 2.5).

Reproductive Performance. Considering both seasons together, 115 cows $(63.2 \%)$ became pregnant during the breeding season. During autumn 102 cows were artificially inseminated and 72 (70.6\%) were pregnant at the end of the breeding season. In spring, 80 animals received AI, and 43 (53.75\%) became pregnant. Significant differences for this variable between seasons were found $(\mathrm{P}=0.020)$.

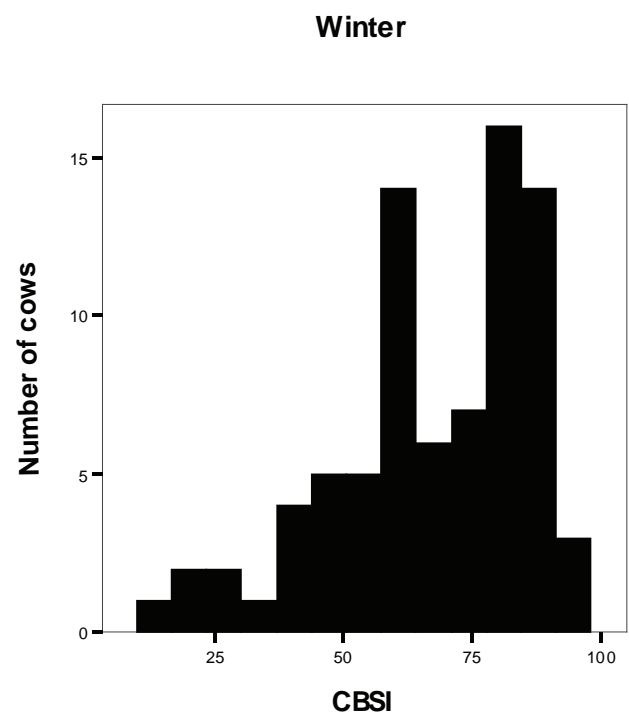

Figure 1. Distribution of interval between calving and the beginning of breeding season (CBSI) for summer and winter breeding seasons. Distribución del intervalo parto-inicio de temporada de servicios para las temporadas de parición de invierno y verano. 
During autumn breeding season cows received on average $2.36 \mathrm{AI}$, while in spring they received in average 1.86 AI. Significant differences were found for number of AI between seasons $(\mathrm{P}=0.003)$. In spring, less AI per cow were required than in autumn. Likewise, cows affected by subclinical mastitis $(\mathrm{P}=0.047)$ and SCC (on average during the breeding season) $>200,000$ cells $/ \mathrm{mL}$ $(\mathrm{P}=0.038)$ received more services than healthy cows or those with lower SCC.

DFAI average was 20.01 with a range of 4 to 80 days. The DFAI were significantly higher in cows with SCC > 200,000 cells $/ \mathrm{mL}(\mathrm{P}=0.048)$. Cows with CBSI of $1-30$ days had more DFAI compared with those with 31-60 and $>60$ CBSI $(\mathrm{P}<0.001)$.

DEAI general average was 43.06 days with a range between 5 and 106 days. Cows calving in winter had lower DEAI $(\mathrm{P}<0.001)$ than cows calving in summer. Other variables that increased DEAI significantly were CBSI of 1 to 30 days $(\mathrm{P}=0.022)$ and presentation of acidosis $(\mathrm{P}=0.045)$.

SCC average during the breeding season was 494,961 cells $/ \mathrm{mL}$, being higher in cows in their third to fifth lactation $(\mathrm{P}=0.023)$. Fifty three cases of clinical and subclinical mastitis were registered. Mastitis pathogens were isolated from 29 samples (54.7\%), while the remainder yielded no bacterial growth. The most prevalent pathogens (55.17\% of the isolates) were non agalactiae streptococci. Other pathogens isolated were: Staphylococcus aureus (24.14\%); coliforms (17.24\%) and others (Arcanobacterium pyogenes and yeasts) (3.45\%). Summer samples were 3.10 times more likely to yield a mastitis pathogen than winter ones $(\mathrm{P}=0.049)$.

\section{ASSOCIATION BETWEEN EXPLANATORY AND OUTCOME VARIABLES}

Significant associations between pregnancy at the end of breeding season $(\mathrm{P}<0.20)$ and breeding season, assistance at parturition, lactation number, reproductive treatment administration, CBSI, BCS (2.5 or less and > 2.5); anoestrous and SCC (average lower or higher than 200000 cells/ $\mathrm{mL}$ along the study period) were found (table 2).

Autumn bred cows were 2.36 times (95\% CI 1.27 4.38) more likely to become pregnant than those bred in the spring. Cows with normal parturition (calved without assistance) were 1.79 times (95\% CI 0.94 - 3.42) more likely to become pregnant than cows that received assistance at calving. Cows in first and second lactation were 1.69 times (95\% CI $0.92-3.10)$ more likely to become pregnant than older cows. Animals without hormonal treatments were 2.79 times (95\% CI 1.44 - 5.40) more likely to become pregnant than those receiving such treatments. Cows with BCS greater than 2.5 were 2.57 times (95\% CI 1.33 - 4.97) more likely to become pregnant than those with BCS lower than 2.5. Animals that were cycling at the beginning of the season were 13.33 times (95\% CI 1.6 - 111.11) more likely to become pregnant than those in anestrous. Animals with average SCC $<200,000$ cells/mL during the breeding season were 2.5 times more likely (95\% CI 1.13 - 4.08) to become pregnant than cows with greater SCC. The proportion of non pregnant animals in the 1-30 days interval was $66.7 \%$, while for the 31-60 and more than 60 days intervals it was $30.8 \%$ and $33.3 \%$, respectively (table 2 ).

Lactation number, calving season, CBSI, clinical and subclinical mastitis and SCC were significantly associated with AI number. The rest of the variables were not significant. Classification of the animals according to the number of services and the association with each variable are shown in table 3.

The probability of receiving more than two AIs was 2.18 times (95\% CI $1.16-4.15)$ higher in cows with 3 or more lactations than in younger ones. Summer calving animals were 1.90 times (95\% CI 0.99 - 3.66) more likely to receive more than two AIs than winter calving ones. Animals with CBSI between 31 and 60 days received more often more than two AIs compared with cows in the other two categories (table 3). Cows with subclinical mastitis were 2.56 times (95\% CI 1.20 - 5.45) more likely to receive more than two AIs during the breeding season than those without the disease. Cows with clinical mastitis were 1.91 times (95\% CI 0.97 - 3.72) more likely to be bred more than two times compared with healthy ones. Cows with an average SCC $>200,000$ cells $/ \mathrm{mL}$ were 2.58 times (95\% CI 1.30 - 5.13) more likely to receive more than two AIs during the season than those with lower counts.

\section{LOGISTIC REGRESSION}

Variables with a significance $<0.20$ at the univariate $\chi^{2}$ - test with the status at the end of breeding season were included in a logistic regression model, with status (pregnant or nonpregnant) as dependent variable. Variables that were significant to the model were: lactation number $(\mathrm{P}=0.031)$, assistance at calving $(\mathrm{P}=0.003)$, reproductive treatment application ( $\mathrm{P}=0.004)$, CBSI 1 to 30 days $(\mathrm{P}=0.002)$, CBSI 30 to 60 days $(\mathrm{P}=0.001)$, CBSI more than 60 days $(\mathrm{P}=0.001)$ and body condition score $(\mathrm{P}=$ 0.007) (table 4).

Cows with less than 2 lactations showed an average CBSI of 63 days, which was higher $(P=0.047)$ than the CBSI observed in cows with more than 2 lactations (55.96 days). Moreover, the percentage of cows with a CBSI greater than 60 days was $60.4 \%$ and $41.8 \%$ for cows less than 2 lactations and more than two lactations, respectively.

Variables associated with number of AIs along the season with $\mathrm{P}<0.20$ were included in the logistic regression model. Breeding season $(\mathrm{P}=0.046)$ and subclinical mastitis $(P=0.030)$ were the significant variables in the model. Cows with subclinical mastitis were 2.35 more 
Table 2. Definition and distribution of explanatory variables selected $(\mathrm{P}<0.20)$ by univariate analysis, for potential association with pregnancy.

Definición y distribución de las variables explicativas seleccionadas en el análisis univariado por asociación potencial con preñez $(\mathrm{P}<0,20)$.

\begin{tabular}{|c|c|c|c|c|c|}
\hline \multicolumn{2}{|c|}{ Independent Variable } & \multicolumn{2}{|c|}{ Pregnancy } & \multirow{2}{*}{ Total } & \multirow{2}{*}{$P$} \\
\hline & & No (67) & Yes (115) & & \\
\hline \multirow{2}{*}{ Lactation number } & $1-2$ & 28 & 63 & 91 & \multirow{2}{*}{0.091} \\
\hline & $>2$ & 39 & 52 & 91 & \\
\hline \multirow{2}{*}{ Breeding season } & Summer & 30 & 72 & 102 & \multirow{2}{*}{0.019} \\
\hline & Winter & 37 & 43 & 80 & \\
\hline \multirow{2}{*}{ Type of partum } & Normal & 41 & 85 & 126 & \multirow{2}{*}{0.073} \\
\hline & Assisted & 26 & 30 & 56 & \\
\hline \multirow{3}{*}{ CBSI (days) } & $1-30$ & 16 & 8 & 24 & \multirow{3}{*}{0.005} \\
\hline & $31-60$ & 20 & 45 & 65 & \\
\hline & $>60$ & 31 & 62 & 93 & \\
\hline \multirow{2}{*}{ Hormonal Treatment } & No & 17 & 56 & 73 & \multirow{2}{*}{0.002} \\
\hline & $\mathrm{Si}$ & 50 & 59 & 109 & \\
\hline \multirow{2}{*}{$\mathrm{BCS}$} & $\leq 2.5$ & 47 & 50 & 97 & \multirow{2}{*}{0.004} \\
\hline & $>2.5$ & 19 & 52 & 71 & \\
\hline \multirow{2}{*}{ Anestrous } & No & 60 & 114 & 174 & \multirow{2}{*}{0.004} \\
\hline & Yes & 7 & 1 & 8 & \\
\hline \multirow{2}{*}{ Acidosis } & No & 66 & 111 & 177 & \multirow{2}{*}{0.0429} \\
\hline & Yes & 1 & 4 & 5 & \\
\hline \multirow{2}{*}{ Retained placenta } & No & 65 & 110 & 175 & \multirow{2}{*}{0.645} \\
\hline & Yes & 2 & 5 & 7 & \\
\hline \multirow{2}{*}{ Endometritis } & No & 61 & 111 & 172 & \multirow{2}{*}{0.118} \\
\hline & $\mathrm{Si}$ & 6 & 4 & 10 & \\
\hline \multirow{2}{*}{ Foot diseases } & No & 64 & 108 & 172 & \multirow{2}{*}{0.646} \\
\hline & Yes & 3 & 7 & 10 & \\
\hline \multirow{2}{*}{ Subclinical mastitis } & No & 29 & 65 & 94 & \multirow{2}{*}{0.192} \\
\hline & Yes & 22 & 31 & 53 & \\
\hline \multirow{2}{*}{ Clinical mastitis } & No & 48 & 81 & 129 & \multirow{2}{*}{0.863} \\
\hline & Yes & 19 & 34 & 53 & \\
\hline \multirow{2}{*}{$\mathrm{SCC}$} & $<200.000$ cells/ML & 20 & 55 & 75 & 0017 \\
\hline & $>200.000$ cells $/ \mathrm{mL}$ & 47 & 60 & 107 & \\
\hline
\end{tabular}

likely (95\% CI 1.09 - 5.07) of receiving more than two services than healthy ones. Likewise, those cows bred in autumn were 2.28 more (95\% CI 1.02 - 5.13) likely of being bred more than two times compared with spring bred ones (table 5).

\section{DISCUSION}

Few studies have attempted to estimate the association between subclinical and clinical mastitis and reproductive performance in seasonally calving dairy herds under grazing conditions (Berry et al 2007, Roche et al 2007). Furthermore, there are no previous reports addressing this subject in South American pastured-based systems. In the present study a complete dataset of a seasonally calving herd under grazing conditions was obtained, and although limited in number, it allowed to exploring these associations under field conditions.

Cows with $\leq 2$ lactations were two times more likely to become pregnant than those with more lactations. This relationship could be associated with the age of the cows since there is a higher risk of postpartum problems in old- 
Table 3. Definition and distribution of explanatory variables selected $(\mathrm{P}<0.20)$ by univariate analysis, for potential association with number of services.

Definición y distribución de las variables explicativas seleccionadas por el análisis univariado por asociación potencial con número de servicios $(\mathrm{P}<0,20)$.

\begin{tabular}{|c|c|c|c|c|c|}
\hline \multicolumn{2}{|c|}{ Independent Variable } & \multicolumn{2}{|c|}{$\begin{array}{c}\text { Number of services during } \\
\text { breeding season }\end{array}$} & \multirow[t]{2}{*}{ Total } & \multirow[t]{2}{*}{$\mathrm{P}$} \\
\hline & & $\leq 2(125)$ & $>2(57)$ & & \\
\hline \multirow{2}{*}{ Lactation number } & $1-2$ & 70 & 21 & 91 & \multirow{2}{*}{0.017} \\
\hline & $>2$ & 55 & 36 & 91 & \\
\hline \multirow{2}{*}{ Breeding season } & Summer & 64 & 38 & 102 & \multirow{2}{*}{0.051} \\
\hline & Winter & 61 & 19 & 80 & \\
\hline \multirow{2}{*}{ Type of partum } & Normal & 85 & 41 & 126 & \multirow{2}{*}{0.594} \\
\hline & Assisted & 40 & 16 & 56 & \\
\hline \multirow{3}{*}{ CBSI (days) } & $1-30$ & 18 & 6 & 24 & \multirow{3}{*}{0.086} \\
\hline & $31-60$ & 38 & 27 & 65 & \\
\hline & Longer than 60 & 69 & 24 & 93 & \\
\hline \multirow{2}{*}{ Hormonal treatment } & No & 54 & 19 & 73 & \multirow{2}{*}{0.208} \\
\hline & Yes & 71 & 38 & 109 & \\
\hline \multirow{2}{*}{$\mathrm{BCS}$} & $\leq 2,5$ & 68 & 29 & 97 & \multirow{2}{*}{0.729} \\
\hline & $>2,5$ & 48 & 23 & 71 & \\
\hline \multirow{2}{*}{ Anestrous } & No & 118 & 56 & 174 & \multirow{2}{*}{0.224} \\
\hline & Yes & 7 & 1 & 8 & \\
\hline \multirow{2}{*}{ Acidosis } & No & 123 & 54 & 177 & \multirow{2}{*}{0.178} \\
\hline & $\mathrm{Si}$ & 2 & 3 & 5 & \\
\hline \multirow{2}{*}{ Retained placenta } & No & 121 & 54 & 175 & \multirow{2}{*}{0.382} \\
\hline & Yes & 4 & 3 & 7 & \\
\hline \multirow{2}{*}{ Endometritis } & No & 117 & 55 & 172 & \multirow{2}{*}{0.342} \\
\hline & Yes & 8 & 2 & 10 & \\
\hline \multirow{2}{*}{ Foot diseases } & No & 116 & 56 & 172 & \multirow{2}{*}{0.123} \\
\hline & Yes & 9 & 1 & 10 & \\
\hline \multirow{2}{*}{ Subclinical mastitis } & No & 76 & 18 & 94 & \multirow{2}{*}{0.013} \\
\hline & Yes & 33 & 20 & 53 & \\
\hline \multirow{2}{*}{ Clinical mastitis } & No & 94 & 35 & 129 & \multirow{2}{*}{0.057} \\
\hline & Yes & 31 & 22 & 53 & \\
\hline \multirow{2}{*}{ SCC } & $\leq 200.000$ cells $/ \mathrm{mL}$ & 60 & 15 & 75 & 0006 \\
\hline & $>200.000$ cells $/ \mathrm{mL}$ & 65 & 42 & 107 & 0.000 \\
\hline
\end{tabular}

er cows (Chebel et al 2004). It could also be influenced by CBSI, since this was longer in younger cows, which had more time to recover from parturition and start the breeding season in better general condition. Cows with longer CBSI had an increased probability of becoming pregnant compared with those with 1-30 CBSI. This was found also by Morton (2000). In animals with shorter CBSI the beginning of services will coincide with events that cause poor reproductive performance, such as pu- erperal diseases (Loeffler et al 1999), milk production peak (Buckley et al 2003) and both the BCS and body weight (Domecq et al 1997, Buckley et al 2003, Roche et al 2007).

Cavestrany et al (2001) found that pregnancy rates in cows with two or more oestral cycles before the beginning of the breeding season were higher than in those with one or no cycles. This might explain the similarity between the groups with longer CBSI (between 31 and 
Table 4. Logistic regression: variables associated with pregnancy.

Regresión logística: variables asociadas con preñez.

\begin{tabular}{lcccc}
\hline \multicolumn{1}{c}{ Independent variables } & $\beta$ & OR & $95 \%$ IC & P \\
\hline Lactation number $(\leq 2 />2)$ & 0.815 & 2.258 & $1.077-4.473$ & 0.031 \\
Type of partum (Normal/Assisted) & 1.193 & 3.296 & $1.480-7.339$ & 0.003 \\
Hormonal treatment & 1.218 & 3.379 & $1.481-7.707$ & 0.004 \\
CBSI 1-30 days (indicator) & & & & \\
CBSI 31-60 days & 1.998 & 7.304 & $2.241-23.808$ & 0.001 \\
CBSI $>60$ days & 2.040 & 7.688 & $2.372-24.916$ & 0.001 \\
BCS $(\leq 2.5 />2.5)$ & 1.053 & 2.867 & $1.331-6.178$ & 0.007 \\
Constant & -3.343 & & & 0.001 \\
\hline
\end{tabular}

Table 5. Logistic regression: variables associated with the number of services.

Regresión logística: variables asociadas con número de servicios.

\begin{tabular}{lcccc}
\hline Independent variables & $\beta$ & OR & $95 \%$ CI & P \\
\hline Subclinical Mastitis & 0.853 & 2.348 & $1.087-5.071$ & 0.030 \\
Breeding season & 0.826 & 2.284 & $1.017-5.133$ & 0.046 \\
Constant & -1.906 & & & 0.001 \\
\hline
\end{tabular}

60 days and $>60$ days). A longer period of time between calving and the beginning of breeding season with a good post-parturition management would allow the resumption of normal ovarian activity, contributing to improve pregnancy rates.

Parturition considered as "assisted", independently of the assistance grade, diminished the probability of subsequent pregnancy. This finding is in accordance with Berry et al (2007), who found that pregnancy probability was lower in animals that had received assistance at calving. Parturition assistance also increases the probability of retained placenta and uterine disease (Thompson et al 1983; Gearhart et al 1990, Mee 2008) affecting future pregnancy (Le Blanc 2008).

The variable "hormonal treatment" was significant to the model; the non-treated group having higher pregnancy probability. This association might be due to correct endocrine and uterine function after parturition, favouring the subsequent pregnancy on this group. On the other hand, animals that received hormonal therapy were "repeat breeders" within the breeding season and treatments were administered to help them to become pregnant.

The body Condition Score of a dairy cow is an assessment of the proportion of its body fat and provides a reasonably accurate measure of a cow's energy reserve (Gillund et al 2001, Roche et al 2009). This measure has also been related to reproductive parameters such as pregnancy at first service, calving to conception interval and number of services per conception (Cavestrany et al
2001, Gillund et al 2001, Buckley et al 2003, Tillard et al 2008). In the present study, we also observed a relationship between BCS and pregnancy, since cows with low BCS had a lower likelihood of becoming pregnant. This agrees with several studies that have found lower pregnancy rates at first service depending on the BCS lost and the length of the postpartum negative energetic balance (Roche et al 2007, Tillard et al 2008). These findings also explain that animals with CBSI longer than 60 days were more likely to become pregnant, since they had more time to finish the negative energetic balance, gain weight and start cycling at the beginning (or around) of the next breeding season. Different studies (Roche et al 2007, Berry et al 2003) have shown that reproductive performance (including reproductive diseases such as anestrous) were negatively affected when BCS measures indicated an increased severity and duration of the postpartum negative energy balance. In our study, anestrous was associated in the univariate analysis but it was not significantly associated with the pregnancy status in the logistic regression. The low number of anestrous cases diagnosed and the association between BCS and reproductive performance may explain this behaviour.

The mechanism(s) by which mastitis may influence reproductive performance is unknown. However, different potential explanations have been suggested (Barker et al 1998, Schrick et al 2001, Santos et al 2004). More recently studies that induced experimental clinical mastitis in cows contributed to clarify the effects of mammary 
inflammation in hormonal profiles (Hockett et al 2000, Hockett et al 2005). Results of those studies demonstrated an ovarian abnormal activity mediated by an increased cortisol secretion, implantation failure as a consequence of $\mathrm{PGF}_{2 \alpha}$ production coupled to a higher uterine sensitivity to this hormone, and diminished secretion and activity of LH and FSH.

The increase in milk somatic cells is a consequence of the passage of polymorphonuclear cells from blood vessels to the mammary gland in response to the release of inflammatory mediators (Harmon 1994). Therefore, it has been suggested that this mechanism could be similar in animals suffering subclinical mastitis, causing poor reproductive performance (Schrick et al 2001).

In this study no association between clinical mastitis and pregnancy and number of services was found. This could be partly explained by the time of disease presentation. Different studies (Barker et al 1998, Santos et al 2004) showed that the effect of clinical mastitis on reproductive performance could be higher when it appears before the first service and between the first service and pregnancy diagnosis. Clinical mastitis cases occur more frequently during early lactation (Dingwell et al 2003) which allows animals to recover normal cyclicity before the breeding season in seasonal calving dairy cows. The simultaneous occurrence of these two events (clinical mastitis and service) would be less probable in reproductive management systems such as the one used at the farm of the present study, except for animals with short CBSI.

Calving season was the second significant variable in the logistic regression for number of services. Summer calving cows had more chances of receiving more than two services than winter calving ones. Several authors described poor reproductive response caused by heat stress as a latter response even in autumn (Wolfenson et al 2000, Jordan 2003). Wolfenson et al (2000) reported as possible latter consequences of heat stress in reproductive performance: a) disturbance in the follicular dynamics, b) lower secretion of follicular steroids and c) poor quality of oocytes. Therefore, it might be suggested that the association between calving season and number of services would be explained by heat stress effects on reproductive performance, especially in animals calved in the second half of the summer calving season. Heat stress effects decrease while climatic conditions improve, and so, animals that did not become pregnant initially might do so after a few services (Jordan 2003). This explains the association between calving season and number of services but not pregnancy state at the end of the season.

It can be concluded that clinical mastitis did not affect reproductive performance (measured by pregnancy at the end of breeding season) in the seasonal calving herd under the pasture-based management system studied. Other factors, such as BCS, CBSI, reproductive treatments application, lactation number, and need of assistance at parturition, had a direct influence in reproductive performance.
Subclinical mastitis affected reproductive performance influencing the number of services. Also, calving season impacted the number of services since summercalving cows needed more services to become pregnant. These observations may help to achieve better reproductive performance in seasonal calving herds under pasture-based management conditions similar to those that predominate in the central dairy area of Argentina.

\section{REFERENCES}

Barker AR, FN Schrick, MJ Lewis, HH Dowlen, SP Oliver. 1998. Influence of clinical mastitis during early lactation on reproductive performance of Jersey cows. J Dairy Sci 81, 1285-1290.

Berry DP, F Buckley, P Dillon, RD Evans, M Rath, RF Veerkamp. 2003. Genetic relationships among body condition score, body weight, milk yield, and fertility in dairy cows. J Dairy Sci 86, 2193-2204.

Berry DP, JM Lee, KA Macdonald, JR Roche. 2007. Body Condition Score and weight effects on dystocia and Stillbirths and consequent effects on postcalving performance. $J$ Dairy Sci 90, 4201-4211.

Blosser TH. 1979. Economic losses from and the National Research Program on mastitis in the United States. J Dairy Sci 62, 119-127.

Bradley AJ. 2002. Bovine Mastitis: An Evolving Disease. Vet $J 164,116-128$.

Buckley F, KO Sullivan, JF Mee, RD Evans, P Dillon. 2003. Relationships among milk yield, body condition, cow weight, and reproduction in spring-calved Holstein Friesians. J Dairy Sci 86, 2308-2319.

Caraviello DZ, KA Weigel, GE Shook, PL Ruegg. 2005. Assessment of the impact of somatic cell count on functional longevity in Holstein and Jersey Cattle Using Survival Analysis Methodology. J Dairy Sci 88, 801-811.

Cavestrany D, CS Galina, C Viñoles. 2001. Effect of the characteristics of the postpartum onset of ovarian activity on the reproductive efficiency of Holstein cows in pastoral conditions. Arch Med Vet 33, 217-226.

Chebel RC, JEP Santos, JP Reynolds, RLA Cerri, SO Juchem, M Overton. 2004. Factors affecting conception rate after artificial insemination and pregnancy loss in lactating dairy cows. An Rep Sci 84, 239-255.

Dingwell RT, KE Leslie, YH Schukken, JM Sargeant, LL Timms. 2003. Evaluation of the Californian mastitis test to detect an intramammary infection with a major pathogen in early lactation dairy cows. Can Vet J 44, 413-416.

Domecq JJ, AL Skidmore, W Lloyd, JB Kaneene. 1997. Relationship between body condition scores and conception at first artificial insemination in a large dairy herd of high yielding Holstein cows. J Dairy Sci 80, 113-120.

Edmonson AJ, IJ Lean, LD Weaver, T Farver, G Webster. 1989. A body condition scoring chart for Holstein dairy cows. $J$ Dairy Sci 72, 68-78.

Gearhart MA, CR Curtis, HN Erb, RD Smith, CJ Sniffen, LE Chase, MD Cooper. 1990. Relationship of changes in condition score to cow health in Holsteins. J Dairy Sci 73, 3132-3140.

Gillund P, O Reksen, YT Gröhn, K Karlberg. 2001. Body Con- 
dition related to ketosis and reproductive performance in Norwegian dairy cows. J Dairy Sci 84,1390-1396.

Gröhn YT, SW Eicker, V Ducrocq, JA Hertl. 1997. Modelling the effect of a disease on culling: an illustration of the use of time dependent covariates for survival analysis. J Dairy Sci 80, 1755-1766.

Gröhn YT, SW Eicker, V Ducrocq, JA Hertl. 1998. Effect of diseases on the culling of Holstein dairy cows in New York State. J Dairy Sci 81, 966-978.

Hockett ME, MF Hopkins, MJ Lewis, AM Saxton, HH Dowlen, SP Oliver, FN Schrick. 2000. Endocrine profiles of dairy cows following experimentally induced clinical mastitis during early lactation. Anim Repr Sci 51, 241-251.

Hockett ME, RE Almeida, NR Rohrbach, SP Oliver, HH Dowlen, FN Schrick, F.N. 2005. Effects of induced clinical mastitis during preovulation on endocrine and follicular function. J Dairy Sci 88, 2432-2431.

Houben EH, AA Dijkhuizen, JA Van Arendonk, RB Huirne. 1993. Short and Long-term production losses and repeatability of clinical mastitis in dairy cattle. J Dairy Sci 76, 2561-2578.

Morton J. 2000. The In Calf Project-some risk factors for reproductive performance in Australian dairy herds. Proceedings of the Australian and New Zealand Combined Dairy Veterinarians Conference, Port Vila, Vanutau, New Zealand.

Jordan ER. 2003. Effects of heat stress on reproduction. J Dairy Sci 86, 104-114.

Klaas IC, U Wessels, H Rothfuss, BA Tenhagen, W Heuwieser, E Schallengerger. 2004. Factors affecting reproductive performance in German Holstein-Friesian cows with a special focus on postpartum mastitis. Liv Prod Sci 86, 233-238.

Le Blanc S. 2008. Postpartum uterine disease and herd reproductive performance. A review. Vet J 176, 102-114.

Loeffler SH, MJ de Vries, YH Schukken. 1999. The effects of time of disease occurrence, milk yield, and body condition on fertility of dairy cows. J Dairy Sci 82, 2589-2604.

Mc Dougall S. 2006. Reproduction performance and management of dairy cattle. J Rep Dev 52, 185-194.

Mee JF. 2008 Prevalence and risk factors for dystocia in dairy cattle: A Review. Vet J 176, 91-101.

Oliver SP, RN Gonzalez, JS Hogan, BM Jayarao, WF Owens. 2004. Microbiological procedures for the diagnosis of bo- vine udder infection and determination of milk quality. $4^{\text {th }}$ ed. National Mastitis Council, Verona, WI, USA.

Petrovski KR, M Trajcev, G Buneski. 2006. A review of the factors affecting the costs of bovine mastitis. J S Afr Vet Assoc 77, 52-60.

Risco CA, GA Donovan, J Hernandez. 1999. Clinical mastitis associated with abortion in dairy cows. J Dairy Sci 82, 1684-1689.

Roche JR, KA Macdonald, CR Burke, JM Lee, DP Berry. 2007. Associations among body condition score, body weight, and reproductive performance in seasonal-calving dairy cattle. J Dairy Sci 90, 376-391.

Roche JR, NC Friggens, JK Kay, MW Fisher, KJ Stafford, DP Berry. 2009. Body condition score and its association with dairy cow productivity, health and welfare. J Dairy Sci 92 , 5769-5801.

Santos JEP, RLA Cerri, LA Ballou, GE Higginbotham, JH Kirk. 2004. Effect of timming of first clinical mastitis occurrence on lactational and reproductive performance of Holstein dairy cows. An Rep Sci 80, 31-45.

Schrick FN, ME Hockett, AM Saxtom, MJ Lewis, HH Dowlen, SP Oliver. 2001. Influence of subclinical mastitis during early lactation in reproductive parameters. J. Dairy Sci 84, 1407-1412.

Schukken IH, DJ Wilson, F Welcome, L Garrison-Tikofsky, RN Gonzalez. 2003. Monitoring udder health and milk quality using somatic cell counts. Vet Res 34, 579-596.

Thompson JR, EJ Pollak, CL Pelssier. 1983. Interrelationships of parturition problems, production of subsequent lactation, reproduction, and age at first calving. J Dairy Sci 66, 1119-1127.

Tillard E, P Humblot, B Faye, P Lecompte, I Dohoo, F Bocquier. 2008. Postcalving factors affecting conception risk in Holstein dairy cows in tropical and sub-tropical conditions. Theriogenology 69, 443-445.

Verkerk G. 2003. Pasture-based dairying: challenges and rewards for New Zealand producers. Theriogenology 59, 553-561.

Washburn SP, SL White, JT Green, Jr., GA Benson. 2002. Reproduction, mastitis, and body condition of seasonally calved Holstein and Jersey cows in confinement or pasture systems. J Dairy Sci 85, 105-111.

Wolfenson D, Z Roth, R Meidan. 2000. Impaired reproduction in heat stressed cattle: Basic and applied aspects. An Rep Sci 60-61, 535-547. 